\title{
RANCANGAN AWAL KAPAL PUKAT CINCIN 115 GRT
}

\author{
(Preliminary Design of a 115 GRT Purse Seiner)
}

\author{
Suryadi Halim ${ }^{1}$, Kawilarang WA Masengi ${ }^{2}$ dan Revols DCh Pamikiran ${ }^{2}$. \\ ${ }^{1}$ Program Sarjana, Fakultas Perikanan dan Ilmu Kelautan, Universitas Sam Ratulangi. \\ ${ }^{2}$ Fakultas Perikanan dan Ilmu Kelautan Universitas Sam Ratulangi, Manado, Sulawesi Utara.
}

\begin{abstract}
Merancang kapal merupakan tahapan dalam pembuatan kapal penangkap ikan, termasuk kapal pukat cincin. Penelitian ini dilakukan dengan tujuan memetakan tahapan pembuatan kapal pukat cincin 115 GRT yang dimulai dengan perancangan awal. Informasi cara perencanaan untuk pembuatan kapal baru sulit didapatkan. Untuk itu diperlukan beberapa hal yang perlu dijawab antara lain bagaimana cara mendesain baru kapal pukat cincin berkapasitas 115 GRT, kecepatan 11 knot dan jumlah pendega 10 orang, serta memberikan alternatif pengembangan terhadap desain kapal pukat cincin menjadi kapal yang lebih efisien guna memperlancar pengoperasian alat tangkap pukat cincin khususnya di Sularesi Utára. Berdasarkan hasil penelitian maka diperoleh rancangan awal kapal ikan pukat cincin yang memiliki Lbp $27,23 \mathrm{~m}$, Lwl 27,78 m B $6,10 \mathrm{~m}$, D 2,95 m dan d 2,51 m, displacement 300,03 ton, daya angkut 145,02 ton dan daya muat ruang ikan 115,00 ton.
\end{abstract}

Kata kunci: kapal, pukat cincin, rancangan, Sulawesi Utara.

Designing is a stage in the manufacturing of fishing vessels, including purse seiner. This study was conducted with the aim of mapping the stages of manufacturing a $115 \mathrm{GT}$ purse seiner. Basic requirements set for the newly designed purse seiner were as follows: has capacity of 115 GRT, speed of 11 knots and manned by 10 crews, as well as able to provide an alternative for the development of purse seiner vessel design for more efficient purse seine fishing in North Sulawesi. This study has resulted in a preliminary design of a purse seiner that has dimensions of Lop $27.23 \mathrm{~m}$, Lwl $6.10 \mathrm{~m} \mathrm{27.78} \mathrm{B,} \mathrm{D} 2.95 \mathrm{~m}$ and d $2.51 \mathrm{~m}$; displacement of 300.03 tons, carrying capdcity of 145.02 tons and load capacity of 115.00 tons of fish.

Keywords: vessel, purse seine, design, North Sulatwesi.

\section{PENDAHULUAN}

Pembuatan kapal pukat cincin dî́ Sufawesi Utara masih menggunakan pengetahuan berdasarkan pengalaman para pembuat secara non formal. Informasi cara perencanaan untuk pembuatan kapal baru sulit didapatkan. Untuk itu diperlukan beberapa hal yang perlu dijawab antara lain bagaimana cara mendesain barukapal pukat cincin serta memberikan alternatif pengembangan terhadap desain kapal pukat eincin menjadi kapal yang lebih efisien guna memperlancar pengoperasian alat tangkap pukat cincin khususnya di Sulawesi Utara.

Menganalisa suatu rancangan kapal, biasan $(a)$ seluruh syarat-syarat permintaan perencanaan seperti tipe kapal, daya muat, kecepatan dan peralatan perlengkapan kapal telah ditentukan oleh pemilik kapal (owner requirement). Bila instruksi pemilik batas-batas persyaratan perencanaan tersebut dipadukan dengan pertimbangan-pertimbangan perancang maka akan dihasilkan suatu hasil rancangan yang optimal.

Dalam pembuatan kapal baru, ukuran utama kapal yang terdiri dari Panjang (L), Lebar (B) dan Dalam (D) harus ditentukan terlebih dahulu secara teliti untuk menentukan bentuk dan kapasitas kapal.

Stabilitas kapal tergantung pada beberapa faktor antara lain dimensi kapal, bentuk badan kapal dan sudut kemiringan kapal terhadap bidang horisontal dan yang paling penting adalah jarak dari titik gravitasi ke metasenter (GM), KG dan KG/D. (Muckle, 1978; Nomura and Yamazaki, 1977).

Tahanan kapal pada suatu kecepatan adalah gaya fluida yang bekerja pada kapal sedemikian rupa sehingga melawan gerakan kapal tersebut. Selama kapal bergerak selalu akan dipengaruhi oleh tahanan gesek yang merupakan tahanan terbesar dari tahanan lain seperti tahanan fluida, gelombang dan tahanan tekanan (Harvald, 1982; Yamamoto, 1982).

Kapal penangkap ikan pukat cincin dipakai khusus untuk menangkap ikan, termasuk menampung, menyimpan, mendinginkan atau mengawetkan ikan dengan menggunakan alat penangkap ikan pukat cincin (PP No. 51 dan 54 Tahun 2002). Kapal ini diperuntukan menangkap ikan pelagis dengan menggunakan jaring pukat cincin yang 
umumnya berbentuk empat persegi panjang dengan banyak cincin di bagian bawahnya. Cara operasinya adalah dengan melingkarkan jaring mengurung gerombolan ikan. Setelah ikan terkurung bagian bawah jaring ditutup dengan menarik tali yang dilewatkan pada cincin-cincin di bagian bawah jaring (PIPP, 2013; FAO, 2013)

\section{METODE PENELITIAN}

Penelitian ini dilakukan di Fakultas Perikanan dan Ilmu Kelautan Universitas Sam Ratulangi Manado. Sumber data sekunder yang digunakan adalah data-data ukuran utama kapal pukat cincin yang telah dibuat dan masih beroperasi dalam usaha penangkapan ikan, khususnya yang menggunakan alat bantu power block. Data ini digunakan sebagai data pembanding pada ukuran utama kapal yang akan dirancang. Metode yang digunakan adalah trial and error dan kapal pembanding, sedangkan hasil perhitungan dikoreksi dengan metode spiral (Okumete, 2009).

Perhitungan diawali dengan mengestimasi ukuran utama kapal berupa Panjang (LBP), Lebar (B), Dalam (D) dan Benaman (d) berdasarkan daya angkut kapal dan kecepatan. Kemudian dilakukan estimasi sementara berupa estimasi ukuran utama, bentuk kapal dan displacement. Setelah itu dilas kukan penilaian awal stabilitas yang terdiri dari perkiraan letak titik berat dan stabilitas awal, pe ngecekan periode ayunan. Setelah semua dinyatakan sesuai, maka kegiatan selanjutnya adalah proses pembuatan rencana garis.

\section{Estimasi ukuran utama}

Perencanaan kapal pukat cincin dalam menentukan ukuran utama kapál menggunakan pendekatan ukuran muatan, Kecepatan, pendega dan jenis kapal. Untûk ukuran tersebut telah ditetapkan, yaitu:

- Muatan terdaftar 15 GRT,

- Kecepatan: 11 krot,

- Pendega; 10orang,

- Jenis kapaY. Pukat cincin.

- Penghitungan ukuran utama kapal dilakukandengan menggunakan rumus pendekatan berdasarkan Traung (1960), yaitu:

- $\mathrm{L}_{\mathrm{bp}}=(5,30$ hingga 5,60$) \times \sqrt[3]{\mathrm{GT}}$,

- $\mathrm{B}=\left(0,11 \times \mathrm{L}_{\mathrm{bp}}\right)+(2,9$ hingga 3,1$)$,

- $\mathrm{D}=0,068 \times \mathrm{L}_{\mathrm{bp}}+(0,9$ hingga 1,1$)$,

- $\mathrm{d}=0,85 \times \mathrm{D}$

- Koreksi terhadap angka Froude: $F_{\mathrm{r}}=\frac{\mathrm{V}}{\sqrt{\mathrm{g} \times \mathrm{L}_{\mathrm{bp}}}}$ (batasan $0,3 \leq \mathrm{F}_{\mathrm{r}} \leq 0,35$ ).

\section{Estimasi bentuk kapal}

Bentuk kapal ikan beragam, ada yang ramping hingga gemuk, keadaan ini digambarkan oleh koefisien bentuk diantaranya adalah koefisien balok $\left(C_{b}\right)$, tengah kapal $\left(C_{m}\right)$, prismatik $\left(C_{p}\right)$ dan garis air $\left(\mathrm{C}_{\mathrm{w}}\right)$. Koefisien tersebut dapat dihitung dengan rumus perhitungan sebagai berikut:

- Batasan harga koefisien balok $\left(\mathrm{C}_{\mathrm{b}}\right)$ untuk kapal ikan jenis pukat cincin antara $0,57-0,68$, maka harga yang direncanakan sebesar 0,68.

- Batasan harga koefisien tengah kapal (C $\mathrm{C}_{\text {f }}$ untuk kapal ikan jenis pukat cincin antara $0,91-0,95$, maka harga yang direncanakan sebesar 0,95 .

- Koefisien prismatik, $\mathrm{C}_{\mathrm{p}}=\frac{\mathrm{C}_{\mathrm{b}}}{\mathrm{C}_{\mathrm{m}}}$

- Koefisien garis air $\left(\mathrm{C}_{\mathrm{w}}\right)$ dihitung dengan rumusrumus pendekatan Tamaela (1988):

- Sabit series 60: $\mathrm{C}_{\mathrm{w}}=0,18+0,86 \times \mathrm{C}_{\mathrm{p}}$

- Posdumne: $\mathrm{C}_{\mathrm{w}}=\frac{1+2 \times \mathrm{C}}{\sqrt{3}}$

- Amos Ayres: $G_{\mathrm{w}}=\frac{1463-1,26 \times \mathrm{C}_{\mathrm{b}}}{2,12-2 \times \mathrm{C}_{\mathrm{b}}}$

- Koefisien vertikal prismatik, $\mathrm{C}_{\mathrm{pv}}=\frac{\mathrm{C}_{\mathrm{b}}}{\mathrm{C}_{\mathrm{w}}}$

- Pembuktian dimensi utama kapal sementara yang direncangkan dengan kisaran yang telah ditetapkan berdasarkan data dari Nomura and Yamazaki (1977).

\section{Estimasi displacement}

Displacement kapal adalah berat kapal dalam keadaan kosong $\left(\mathrm{W}_{\mathrm{ls}}\right)$ ditambah dengan daya angkut $\left(D_{a}\right)$ kapal dengan satuan ton. Berat kapal dalam keadaan kosong terdiri dari berat lambung kapal $\left(\mathrm{W}_{\text {hull }}\right)$, deck planking $\left(\mathrm{W}_{\text {deck }}\right)$, insulation $\left(\mathrm{W}_{\text {ins }}\right)$, instalasi mesin $\left(\mathrm{W}_{\mathrm{ep}}\right)$, outfitting dan peralatan $\left(\mathrm{W}_{\mathrm{o}+\mathrm{eq}}\right)$, serta berat lainnya $\left(\mathrm{W}_{\mathrm{etc}}\right)$ (Watson, 2002).

Daya angkut kapal $\left(\mathrm{D}_{\mathrm{a}}\right)$ terdiri dari berat bahan bakar $\left(\mathrm{W}_{\mathrm{bb}}\right)$, minyak pelumas $\left(\mathrm{W}_{\mathrm{mp}}\right)$, air tawar $\left(\mathrm{W}_{\mathrm{at}}\right)$, bahan-bahan makanan $\left(\mathrm{W}_{\mathrm{f}}\right)$ awak kapal $\left(\mathrm{W}_{\mathrm{c}}\right)$, dan barang bawaan awak kapal $\left(\mathrm{W}_{\mathrm{i}}\right)$, serta muatan kapal ( $\mathrm{W}_{\text {load }}$ ). Muatan kapal ini merupakan pengurangan dari berat daya angkut yang dibayar (pay load) dengan berat awak kapal, barang bawaan dan barang habis terpakai (Tamaela, 1988).

Setelah nilai displacement diperoleh, estimasi tenaga penggerak kapal dapat dilakukan dengan menggunakan formula admiralty, kemudian nilai tersebut disesuaikan dengan tipe dan daya mesin dari pabrikan mesin diesel. Formula admiralty yang digunakan adalah: $\mathrm{THP}=\Delta^{2 / 3} \times \frac{\mathrm{V}_{\mathrm{s}}{ }^{3}}{\mathrm{C}_{\mathrm{adm}}}$.

Dimana: THP = Trust Horse Power (HP), $\Delta=$ displacement (ton), $\mathrm{V}_{\mathrm{s}}=$ kecepatan kapal (knot), $\mathrm{C}_{\mathrm{adm}}=10\left(\mathrm{~L}_{\mathrm{bp}}{ }^{0,5}+7\right)$, dengan $\mathrm{L}_{\mathrm{bp}}$ satuan kaki. 


\section{Perkiraan letak titik berat dan stabilitas awal}

Penilaian awal stabilitas untuk memperkirakan letak titik berat kapal secara melintang dilakukan berdasarkan rumusan dari Rawson and Tupper (1994) dengan berat kapal sementara secara keseluruhan diukur vertikal dari garis dasar $(\overline{\mathrm{KG}})$, dan secara memanjang (longitudinal centre of gravity/LCG) diukur dari titik tengah kapal (midship). Perkiraan stabilitas awal ditentukan dengan menghitung tinggi atau jarak meta center: $\overline{\mathrm{GM}}=\overline{\mathrm{KM}}-\overline{\mathrm{KG}}$, dengan nilai $(\overline{\mathrm{KM}})$ didapat dari:

$$
\begin{gathered}
\overline{\mathrm{KM}}=\left(\frac{\mathrm{C}_{\mathrm{w}} \times\left(\mathrm{C}_{\mathrm{w}}+0,04\right) \times \mathrm{B}^{2}}{12 \times \mathrm{C}_{\mathrm{b}} \times \mathrm{d}}\right)+\left(\mathrm{d} \times \frac{\mathrm{C}_{\mathrm{w}}}{\mathrm{C}_{\mathrm{w}}+\mathrm{C}_{\mathrm{b}}}\right) \\
\mathrm{LCG}=\frac{\Delta \text { moment }}{\text { displacement }}
\end{gathered}
$$

Untuk perkiraan titik tekan memanjang (longitudinal centre of buoyancy/ LCB) merupakan titik tekan yang ditimbulkan oleh air terhadap badan kapal. Ada tiga rumus pendekatan LCB berdasarkan Lackenby and Milton (1965) untuk mengestimasi LCB yaitu:

- BSRA: $\mathrm{LCB}=\mathrm{L}_{\mathrm{bp}} \times\left(0,20 \times\left(\mathrm{C}_{\mathrm{b}}-0,75\right)\right)$

- Troost: $\mathrm{LCB}=\mathrm{L}_{\mathrm{bp}} \times\left(0,0175 \times\left(\mathrm{C}_{\mathrm{p}}-1,25\right)\right)$

- TNSW: $\mathrm{LCB}=\mathrm{L}_{\mathrm{bp}} \times\left(\left(0,193 \times \mathrm{C}_{\mathrm{p}}\right)-13,30\right)$

Setelah mendapatkan nilai LCG dan LCB, maka estimasi besaran trim dapat dilakukan saat kapal dalam keadaan muatan penuh tanpa ballast dengan menghitung moment Inersia memanjang $\left(\mathrm{I}_{\mathrm{L}}=0,604 \times \frac{\mathrm{L}^{3} \times \mathrm{B}}{10}\right)$ sehingga mendapatkan monent trim persatuan panjang $\left(\mathrm{M}_{\mathrm{CT}}=\mathrm{I}_{\mathrm{L}} \times \frac{\gamma}{\mathrm{L}_{\mathrm{BP}}}\right)$ dân nilai trim $\left(\mathrm{t}=\frac{(\mathrm{LCG}-\mathrm{LCB}) \times \Delta}{\mathrm{M}_{\mathrm{CT}}}\right)$ serta trim buritan $\left(\mathrm{t}_{\mathrm{a}}=\frac{\mathrm{LCB}_{\text {buritan }}}{\mathrm{L}_{\mathrm{BP}}} \times \mathrm{t}\right)$ bisa diperoleh.

Penetapan data awa-dari ukuran utama kapal yang telah didapat berdasarkan hasil perhitungan di pra rancangan digunakan untuk menentukan panjang garis dif $\left(\mathrm{L}_{\mathrm{wl}}=\mathrm{L}_{\mathrm{bp}}+2 \% \mathrm{~L}_{\mathrm{bp}}\right)$, panjang displacement $\left(\mathrm{L}_{\mathrm{disp}}=\left(\mathrm{L}_{\mathrm{wl}}+\mathrm{L}_{\mathrm{bp}}\right) / 2\right)$, kurva prismatik displacement $\left(\delta_{\text {disp }}=\left(L_{c b} / L_{b p}\right) \times \mathrm{C}_{\mathrm{p}}\right)$. Koefisien prismatik untuk bagian depan dan belakang dengan perúmusan $\delta \mathrm{f} / \mathrm{a}=\mathrm{C}_{\mathrm{p}} \pm\left(1,4+\mathrm{C}_{\mathrm{p}}\right) \times \mathrm{c}$, dimana $\mathrm{c}=L_{c b} / L_{b p}$, dan luas midship $\mathrm{A}_{\text {midship }}=$ B.d.C $\mathrm{C}_{\mathrm{m}}$. Jarak antar stasiun $\mathrm{h}_{1}=L_{b p} / 20$. Setelah itu estimasi luasan setiap stasiun dengan tabel NSP. Nilai $\mathrm{L}_{\mathrm{cb}}$ displacement dan $\mathrm{V}_{\text {displacement }}$.

\section{HASIL PENELITIAN}

Kapal pukat cincin yang direncanakan memiliki ciri-ciri sebagai berikut:
- Tempat penyimpanan alat penangkap ikan pukat cincin di bagian belakang kapal.

- Power Block untuk penanganan alat tangkap pukat cincin selama pengoperasian.

- Ruang ikan utama yang memiliki fasilitas pendingin agar ikan terjaga kualitasnya dan ruangan ini ditempatkan di bagian tengah agak ke belakang.

- Kamar mesin terletak pada bagian tengah agak ke depan.

- Kapal ini membutuhkan kapasitas bahan bakar yang tinggi untuk operasi yang lama dan jauh.

- Winch untuk mempercepat dan mémpermudah penarikan tali cincin.

- Kapal harus memiliki fasiltas akomodasi dan dapur untuk Kru Kapal.

Berdasarkan ciri-ciritersebut di atas, maka digunakan beberapa kapałpenbanding jenis kapal pukat cincin yang telah dibangun dan masih aktif hingga saat ini yang mewakili kriteria tersebut.

Data umum kapal pembanding dapat dilihat pada Tabel 1 berikutint.

Tabel 1. Daty statistik kapal pukat cincin yang pernah dibangun.

Table 1.Y Statistical data on existing purse seine vessels.

\begin{tabular}{ccccl}
\hline GT (ton) & LOA (m) & B (m) & D (m) & Nama Kapal \\
\hline 124 & 19,78 & 7,31 & 3,53 & Barbara H \\
176 & 22,31 & 7,62 & 3,93 & Cape Blanco \\
135 & 23,77 & 7,31 & 3,96 & Danilo C \\
251 & 32,91 & 8,53 & 3,65 & Patricia Lynn \\
440 & 36,30 & 8,98 & 5,04 & Eileen Marie \\
417 & 36,57 & 9,98 & 4,57 & El Dorado \\
246 & 36,88 & 8,53 & 3,96 & Amalis \\
258 & 39,50 & 7,50 & 3,20 & Daiichi Maru 25 \\
394 & 40,75 & 8,50 & 3,70 & Dorica \\
765 & 40,86 & 10,00 & 6,60 & Claudia L \\
\hline
\end{tabular}

Sumber: IATTC (2013).

\section{Estimasi ukuran utama}

Ukuran tersebut telah ditetapkan, yaitu:

- Muatan terdaftar: 115 GRT,

- Kecepatan: 11 knot,

- Pendega: 10 orang,

- Jenis kapal: Pukat cincin.

Berdasarkan penetapan di atas maka dilakukan perhitungan $\mathrm{L}_{\mathrm{bp}}, \mathrm{B}$, D dan d, serta dikoreksi dengan menggunakan angka Froude yang hasilnya dapat dilihat pada Tabel 2 berikut ini.

Tabel 2. Estimasi ukuran utama kapal pukat cincin.

Table 2. Estimates of the main dimensions of purse seine vessels.

\begin{tabular}{lccc}
\hline & Kisaran & Ditetapkan & Estimasi (m) \\
\hline $\mathrm{L}_{\mathrm{bp}}$ & $5,30-5,60$ & 5,60 & 27,23 \\
$\mathrm{~B}$ & $2,90-3,10$ & 3,10 & 6,10 \\
$\mathrm{D}$ & $0,90-1,10$ & 1,10 & 2,95 \\
$\mathrm{~d}$ & & & 2,51 \\
\hline
\end{tabular}


Ukuran utama kapal berdasarkan estimasi berpedoman pada kisaran yang dinyatakan oleh Traung (1960), maka didapat ukuran Lbp, B, D dan d dari kapal rancangan. Kemudian ukuran utama ini dikoreksi terhadap nilai Froude dan perbandingan dimensi utama kapal (Tabel 3).

Tabel 3. Koreksi perbandingan ukuran utama kapal rancangan.

Table 3. Corrected main dimensions of ship design.

\begin{tabular}{lcc}
\hline & Nilai & Kisaran \\
\hline $\mathrm{L} / \mathrm{B}$ & 4,47 & $3,09-4,69$ \\
$\mathrm{~L} / \mathrm{D}$ & 9,23 & $5,69-10,39$ \\
$\mathrm{~B} / \mathrm{D}$ & 2,07 & $1,77-2,32$ \\
$\mathrm{~F}_{\mathrm{r}}$ & 0,35 & $0,30-0,35$ \\
\hline
\end{tabular}

Berdasarkan koreksi angka Froude, dimensi utama kapal yang direncanakan ini masih cukup layak karena masih dalam kisaran. Sedangkan nilai perbandingan dimensi ukuran utama kapal juga cukup baik karena masih berada pada kisaran dari kapal pembanding.

\section{Estimasi bentuk kapal}

Estimasi bentuk kapal rancangan tergambar pada nilai koefisien bentuk yang ditampilkan pada tabel 4 berikut ini.

Tabel 4. Estimasi koefisien bentuk kapal rancangan.

Table 4. Estimation of the coefficients of ship

\begin{tabular}{|c|c|c|c|}
\hline & Estimasi & Ditetapkan & Kisaran \\
\hline $\mathrm{C}_{\mathrm{b}}$ & & 0,70 & $0,5760,70$ \\
\hline $\mathrm{C}_{\mathrm{m}}$ & & 0,84 & $0,80-0,95$ \\
\hline$C_{p}$ & 0,83 & 0,83 & $0,67=0,81$ \\
\hline $\mathrm{C}_{\mathrm{w}}$ & & & \\
\hline $\begin{array}{l}\mathrm{C}_{\mathrm{w}} \text { Sabit series } 60 \\
\mathrm{C}_{\mathrm{w}} \text { Posdumpe }\end{array}$ & $\begin{array}{l}0,90 \\
080\end{array}$ & & \\
\hline $\begin{array}{l}\mathrm{C}_{\mathrm{w} \text { Posdumne }} \\
\mathrm{C}_{\mathrm{w}} \text { Amos Ayres }\end{array}$ & $\begin{array}{l}0,80 \\
0,81\end{array}$ & & \\
\hline $\mathrm{C}_{\mathrm{pv}}$ & 0,78 & & \\
\hline
\end{tabular}

Ada dua koefisjen yang ditetapkan nilainya yaitu $\mathrm{C}_{\mathrm{b}}$ dan $\mathrm{C}_{\mathrm{m}}$ berdasarkan kriteria jenis kapal yang akan dirancang, sedangkan untuk $\mathrm{C}_{\mathrm{w}}$ menggunakan tigâ rumusan yaitu Sabit series 60, Posdumne dan Amos Ayres. Nilai hasil dari ke tiga rumus tersebut dipilih nilai yang paling besar yaitu 0,90 sebagai nilai $C_{w}$, sehingga diperoleh juga nilai dari $\mathrm{C}_{\mathrm{pv}}$.

\section{Estimasi displacement}

Displacement kapal berdasarkan estimasi didapat nilai kisaran sebesar 236,29 ton yang terdiri dari berat kosong kapal sebesar 91,26 ton dan berat muatan kapal sebesar 145,02 ton. Estimasi displacement ini lebih kecil dibandingkan dengan perhitungan displacement Archimides sebesar 300,03 ton, maka nilai estimasi displa- cement ini memenuhi syarat untuk digunakan dalam perhitungan selanjutnya.

Nilai displacement yang diperoleh, dilanjutkan dengan estimasi tenaga penggerak kapal yang akan digunakan formula admiralty dengan hasil THP sebesar 317,71 HP. Nilai ini dicocokkan dengan data mesin diesel yang diproduksi, maka dipilih mesin tipe Marine Engine C7 Acert produksi Caterpillar dengan kekuatan 370 HP, 2600 rpm dan pemakaian bahan bakar 77,5 liter/jam.

\section{Perkiraan letak titik berat dan stabilitas awal}

Perkiraan titik berat melintang ini berdasarkan berat kapal sementara secara keseluruhan dan titik berat ini diukur vertikal dari garis dasar. Adapun perhitungan titik berat dapa dilihat pada Tabel 5 berikut ini.

Tabel 5. Perhitungan letak titik berat melintang dari garis dasar.

Table 5. Computation of transverse metacenter from baseline.

\begin{tabular}{|c|c|c|c|}
\hline Bagian & $\begin{array}{c}\text { Berat } \\
\text { (ton) }\end{array}$ & $\begin{array}{c}\text { Jarak } \\
(\mathrm{m})\end{array}$ & $\begin{array}{c}\text { Moment } \\
\text { (ton.m) }\end{array}$ \\
\hline Kulit lambung & 49,45 & 3,80 & 187,91 \\
\hline Kulit deck & 2,88 & 3,70 & 10,64 \\
\hline Instalasi mesin & 11,50 & 3,00 & 34,50 \\
\hline Isolasiffish hold & 10,13 & 3,50 & 35,46 \\
\hline Outfitting \& & 7,42 & 5,00 & 37,09 \\
\hline Muatan & 32,46 & 2,20 & 71,42 \\
\hline Bahan bakar & 100,00 & 0,50 & 50,00 \\
\hline Minyak pelumas & 0,61 & 3,70 & 2,26 \\
\hline Air tawar & 7,80 & 1,80 & 14,04 \\
\hline Bahan makanan & 3,00 & 4,10 & 12,30 \\
\hline Awak kapal & 0,75 & 5,50 & 4,13 \\
\hline Barang bawaan & 0,40 & 4,10 & 1,64 \\
\hline Lain-lain & 9,89 & 3,80 & 37,58 \\
\hline TOTAL & 236,29 & & 498,97 \\
\hline
\end{tabular}

Dari perhitungan berat di Tabel 5, ini didapat total berat sebesar 236,29 ton dan total momen 498,97 ton.m. Maka letak titik berat melintang di atas garis dasar $(\overline{\mathrm{KG}})$ sebesar $2,11 \mathrm{~m}$. Perkiraan stabilitas awal dengan nilai dilakukan dengan menghitung jarak meta center $\overline{\mathrm{GM}}=\overline{\mathrm{KM}}-\overline{\mathrm{KG}}$, dengan $\overline{\mathrm{KM}}$ sebesar 2,89 m dan $\overline{\mathrm{KG}}$ 2,11 m maka $\overline{\mathrm{GM}}$ sebesar $0,78 \mathrm{~m} . \overline{\mathrm{GM}}$ ini lebih besar dibandingkan nilai minimum yang dinyatakan oleh Rawson and Tupper (1994) sebesar 0,75 m.

Kapal yang rancangan dibuat tata letaknya dengan memiliki anjungan, ruang untuk kru, mualim, mesin, gudang dan daun kemudi. Disediakan juga tangki bahan bakar, air dan oli. Tata letak dan penggunaan ruangan di dalam kapal diatur sedemikian rupa agar distribusi beban dapat merata dan seimbang. Untuk lebih jelasnya mengenai tata letak dan penggunaan ruangan di dalam kapal (Gambar 1). 


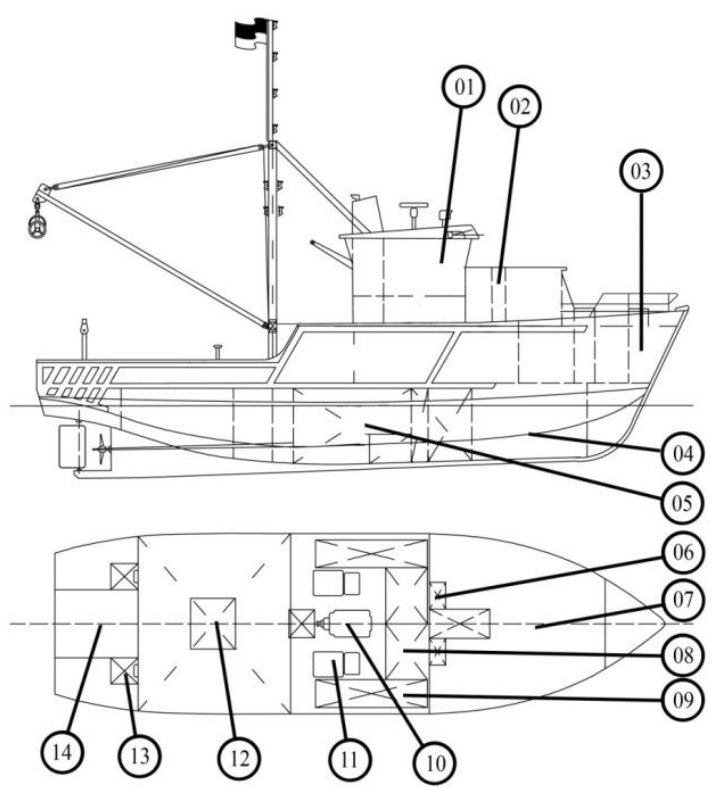

Gambar 1. Tata letak kapal pukat cincin yang dirancang

Figure 1. General arrangement of purse seiner design.

Keterangan:

01. Anjungan
03. Gudang
05. R. mesin
07. R. ABK
09. Tanki Bahan bakar
11. Mesin bantu
13. Gudang

02. R. Mualim

04. R. ABK

06. Tangki air

08. Tangki oli

10. Mesin utama

12. Palka ikan

14. Ruang daun kemudi

Perkiraan titik berat memanjang (LCG) bert dasarkan perhitungan moment pembagian berat kapal yang terdiri dari berat kulit lambung,kulit dek, instalasi mesin, isolasi palka ikan, outfitting dan peralatan. Muatan, bahan bakar, minyak pelumas, air tawar, bahan makanan, awak kapal beserta barang bawaannya juga dihitung perkiraan berat dan letaknya di dalam kapal. Nílai berat dan titik berat secara keseluruhan moment bagian muka dan belakang ini didapat selisih berat sebesar $-99,98$ ton.m, maka titik berat memanjang/LCG berada di belakang midship sejauh $0,33 \mathrm{~m}$.

Berdasarkan BSRA dan Troost, estimasi titik tekan memanjang/LCB terletak di belakang midship sejaub $0,27 \mathrm{~m}$ dan $0,26 \mathrm{~m}$. Untuk estimasi LCB berdasarkan TNSW berada di depan midship sejauh $0,76 \mathrm{~m}$. Maka nilai LCB yang ditetapkan adalah $0,26 \mathrm{~m}$ di belakang midship. Untuk nilai trim diperoleh sebesar 7,85 cm, trim buritan sebesar $3,85 \mathrm{~cm}$.

Berdasarkan data ukuran kapal rancangan maka diperoleh nilai dimensi $\mathrm{L}_{\mathrm{wl}}, \mathrm{L}_{\text {dispacement, }} \mathrm{V}_{\text {displa- }}$ cement dengan kurva displacement koefisien luasan midship 12,84698 $\mathrm{m}^{2}$, jarak antar stasiun $\mathrm{h}_{1}$ sebesar 1,36 m. Berdasarkan perhitungan rencana garis pada kapal rancangan, maka dibuatkan tabel NSP untuk menghitung luasan area pada setiap stasiun dengan luas terbesar berada di stasiun 9 dan 10 yaitu $100 \%$ dari luasan midship. Luasan terkecil berada pada stasiun FP sebesar $0 \%$. $\mathrm{L}_{\mathrm{cb}}$ displacement sebesar -0,1271 $\mathrm{m}$ di belakang midship, serta $\mathrm{V}_{\text {displacement }}$ sebesar 239,9448 $\mathrm{m}^{3}$. Kemudian dikoreksi dengan tabel cant part mendapatkan nilai $\mathrm{L}_{\mathrm{cb}}$ cant part terhadap AP sebesar -0,17665 m di belakang midship, serta $V_{\text {cant part }}$ terhadap AP sebesar $0,1889 \mathrm{~m}^{3}$. Maka total $\mathrm{V}_{\text {disp }}$ sebesar $239,7559 \mathrm{~m}^{3}$ dan $\mathrm{L}_{\mathrm{cb} \text { gabungan }}$ sebesar $-0,1253 \mathrm{~m}$ di belakang midship.

Untuk mengetahui luasan stasiun yang diperoleh dari perhitungan, maka dibuatlah diagram CSA untuk mengetahui antar luasan stasiur membentuk suatu kurva diagram yang segaris serta untuk mengoreksi luasan dari masing-masing stasiun bila mengalami kesalahan atau bila ada perubahan dari $\mathrm{L}_{\mathrm{cb}}$ kapal. Diagram CSA ini dapat dilihat pada Gambar 2.

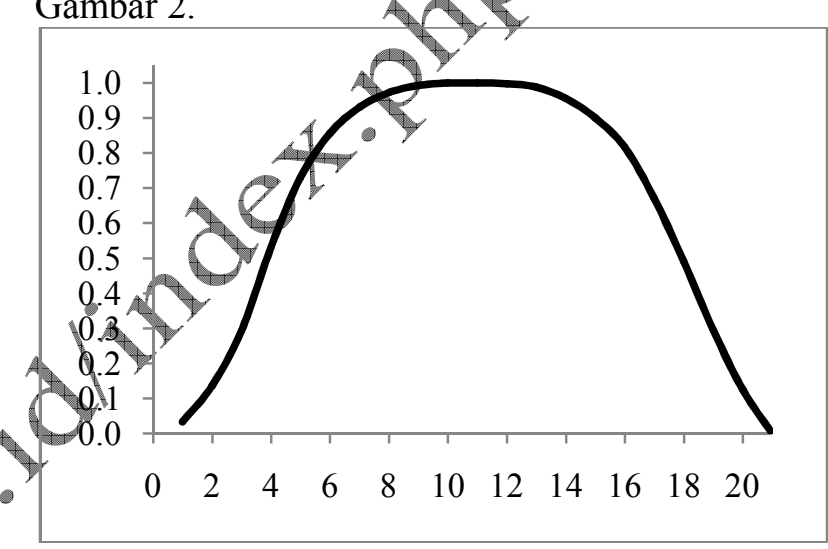

Gambar 2. Diagram CSA kapal pukat cincin yang dirancang

Figure 2. CSA diagram of the purse seiner design.

\section{KESIMPULAN}

Berdasarkan hasil penelitian maka diperoleh kesimpulan yang berhubungan dengan rancangan awal kapal ikan pukat cincin 115 GRT, yaitu:

- Tipe kapal: Pukat cincin

- Kecepatan: 11,00 knot

- $\mathrm{L}_{\mathrm{bp}}: 27,23$ meter

- Panjang garis air: 27,78 meter

- Lebar: 6,10 meter

- Dalam: 2,95 meter

- draft: 2,51 meter

- Displacement: 300,03 ton

- Daya angkut: 145,02 ton

- Daya muat ruang ikan: 115,00 ton

- Cb: 0,70

- Cm: 0,84

- Cp: 0,83

- Cw: 0,90 


\section{DAFTAR PUSTAKA}

Det Norske Veritas. 2001. Part 3 Ch 5: Load line. Rules for classification of ships newbuildings. Hull and equipment main class. Norway. $31 \mathrm{p}$.

FAO. 2013. Fishing Gear Types: Purse Seines. FAO of the United Nations. Fisheries and Aquaculture Department. www.fao.org/fishery/geartype.

IATTC. 2013. Vessel Database. Active purse-seine at InterAmerican Tropical Tuna Commission. www.iattc.org.

Istopo. 1997. Stabilitas kapal. Untuk perwira kapal niaga. Yayasan corps alumni akademi ilmu pelayaran. Jakarta. 336 p.

Lackenby H and Milton D. 1965. DTMB standard series 60. A new presentation of the resistance data for block coefficient, LCB, breadth-draught ratio, and length-breadth ratio variations. British Ship Research Association (BSRA). London. 75p.

Nomura M and Yamazaki T. 1977. Fishing techniques I. Japan international cooperation agency. Tokyo. 205p.

pipp.kkp.go.id. 2013. Deskripsi kategori alat tangkap pukat cincin. Pusat Informasi Pelabuhan Perikanan (PIPP) Kementerian Kelautan dan Perikanan Republik Indonesia.
Peraturan Pemerintah Republik Indonesia Nomor 51, 2002 tentang Perkapalan. Disahkan pada tanggal 23 September 2002.

Peraturan Pemerintah Republik Indonesia Nomor 54, 2002 tentang Usaha Perikanan. Disahkan pada tanggal 7 Oktober 2002 .

Rawson, KJ and EC. Tupper. 1994. Basic Ship Theory. Vol. 1. Hydrostatics and Strength. 4th edition. Longman Group Ltd. England. 375p.

Tamaela MJ. 1988. Rancang Kapal I. Fakultas Teknik perkapalan. Univ. Pattimura. Ambon. 123p.

Técicas Hidráulicas S.A. 2013. Powerblock \$B-38D (Brochure). www.thsa.com.

Traung, JO. 1960. Fishing Boats of the World 2 Fishing News Books Ltd. Roma. 830 p.

Tsudani T. 1983. Illustrations of Japanese fishing boats. Seizando-Shoten Publishing Co.,Ltd. Tokyo. 190p.

Watson, DGM. 2002. Practical Ship Design. Elseiver Science Ltd. Oxford. 558p.

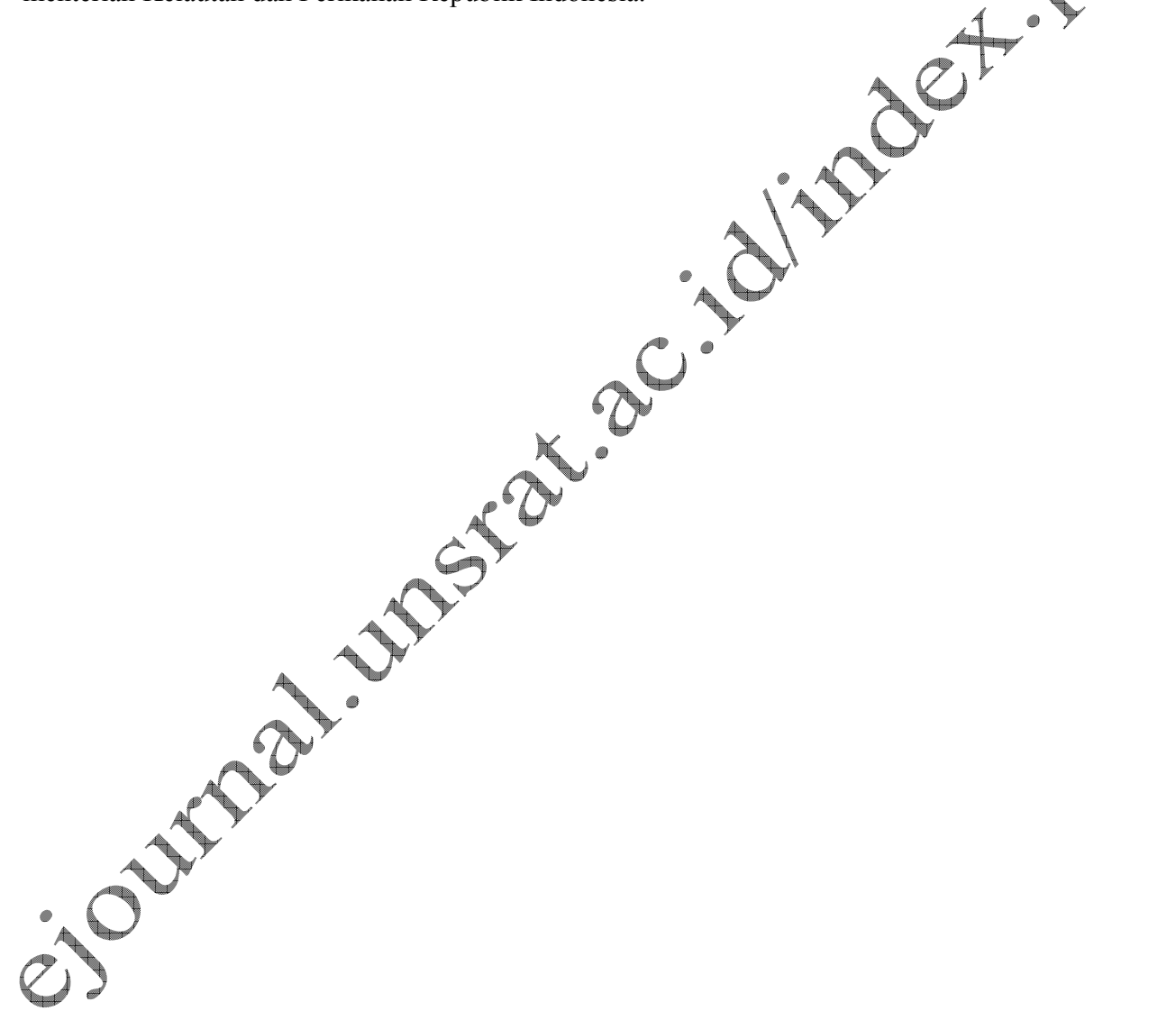

